\title{
Relevance and Commitment in Ezenwa-Ohaeto's Pidgin Poetry Collections
}

\author{
Ogechi Blessing Ezeji \\ http://dx.doi.org//10.4314/ujah.v17i1.3
}

\begin{abstract}
Epigraphs
I made an unbreakable pledge to myself that the people would find their voices in my song.

-Pablo Neruda

Pidgin English na pikin wey no get mama but everybody dey send am message.

-Anonymous
\end{abstract}

\section{Abstract}

The question of relevance and commitment is a recurring one in African literature written in Standard English. This paper seeks to ask the same question with regards to poetry in Pidgin English. The question then becomes- is the poet who writes in pidgin English as committed to the social course of his society as his counterpart who writes in Standard English? If the above question is answered in the affirmative, a follow up question will be: Is there any relationship between his form, in this case, Pidgin English and the content of the message? If this question is also answered in the affirmative, the next question will be:- to what extent do form and content intertwine to give the reader a completely rewarding poetic experience. These questions are answered through the review of Ezenwa-Ohaeto's pidgin poetry collections. The paper makes use of the Marxist critical theory. 


\section{Introduction}

The argument concerning the place of relevance and commitment in literary discourse across the globe and in African literature in particular is a lingering one. It is perhaps the place of relevance and commitment in literature that informs the major dividing line between the formal approaches to literary criticism and their mimetic counterparts. While the formal approaches such as Russian formalism and structuralism insist on literature as mere ecriture consisting of signs and symbols upon which literary appreciation and criticism should be entirely based, the mimetic approaches such as sociological approach, Marxism and lately post colonialism sees literature basically as an off shoot of the society from which clues for its proper interpretation can be drawn. The formalist school has come to be known for its arts for art's sake proposition. Reacting to the art for art's sake proposition, Achebe holds: "Art for art's sake is another piece of deodorised dog-shit." (Morning Yet...19)

Achebe's position is perhaps representative of the position of most African writers on the issue of relevance and commitment. Achebe was to expand his position more in another essay when he writes "that every literature must seek the things that belong unto its peace, must, in other words, speak of a particular place, evolve out of the necessities of its history, past and current, and the aspirations and destiny of its people.(Morning Yet...6). Also justifying the place of relevance and commitment in literature, Soyinka declares: "I believe implicitly that any work of art which opens out the horizons of the human mind, and intellect, is by its very nature, a force of change, a medium for change". As a way of adding his voice, Charles Nnolim made the following declaration:

It is clear that the reader demands of our writers some measure of commitment, some degree of 
courage to challenge the status quo, to change the society long in anomie. The writer must definitely tell us where he stands. He must, in his works, confront the problem of good and evil in his society, differentiate them and take sides; and in taking sides, he must tell us where he stands. (248)

The three quotations above suffice in convincing us as to position of most African writers and critics with regards to the issue of relevance and commitment in literature.

The question of relevance and commitment is further brought to the fore when one takes into cognizance the fact that the Pidgin English is the vehicle of poetic communication in the collections under review. Ezenwa-Ohaeto, no doubt, aligns himself to this same position- that a writer must be committed to the course of his society and his work must be seen as being relevant to the welfare and wellbeing of his society. The message of his poetry reveals this. His use of the Pidgin enhances this position. The remaining part of this paper shall concern itself with analysing how Ezenwa-Ohaeto successfully uses the Pidgin English in making his poetry collections under review committed and relevant to the course of his society.

\section{Theoretical Framework}

The Marxist theory is one of the paradigms upon which a mimetic approach to the criticism of literature is possible. The Marxist theory is based on the tenets of Marxism as articulated by a German philosopher Karl Marx and Fredrick Engel, a sociologist. These tenets of Marxism is articulated in their classical book; The Communist Manifesto. The hallmark of their theses is that the society consists of two opposing socio-economic group in a continuous struggle for survival; the end result shall be either a revolutionary 
reconstruction of the society or a common ruin of the contending classes. The implication of the idea of social reconstruction can be seen in the consciousness raising and consequent assertion of rights amongst social groups that had hitherto been silent. These hitherto silent groups are most times both politically and socially unconscious constituting the repressed elements of the society and therefore need to be restored to the surface. The classical conception of Marxism is therefore a concept of struggle between the superstructure and the base. It is upon this that the conception of Marxism as a critical theory in literature is based.

In a rereading of the works of Karl Marx, a French philosopher, Althusser revised the Marxist theory thereby making it accessible to other theories. The implication of this revision is that the concept of classical Marxism as a two way division and struggle between the base and the superstructure is no longer obtainable. The basis of this is that economic factors alone are not sufficient to explain the way other aspects of the society function. Rather, change results from the process of overlapping of series of contradictions. Scholars and critics have often given Marxist interpretations to a text on the basis of ideology. It may therefore not be out of place for one to wonder the reason for the application of the Marxist theory with regards to the present paper. There is no gainsaying that a poet's ideological stance necessarily influences the form of his poetic output. To this effect, Eagleton notes; "significant development in literary form, then, result from significant changes in ideology. They embody new ways of perceiving social reality and... new relationship between artist and audience." (23) It is therefore right to state that poetic form "crystallizes out of certain dominant ideological structures."

Eagleton's position insists on an essential relationship between form and content. 
Udumukwu posits that "as a people keen on evolving a responsible literary education we cannot ignore the important intersection between ideology and form." (141)

The implication of the above scholarly views is that there exists a relationship between literary form and the ideological leaning of the work in question. It is therefore in the light of the above theoretical and critical propositions that this paper seeks to marry the ideological position of Ohaeto's poetry with his choice of the Pidgin English as a medium of expression. The paper seeks to establish that by virtue of the marriage between the poet's ideological leaning and his choice of the Pidgin English, poetic relevance and commitment is further achieved.

\section{Pidgin English as a Means of Poetic Expression}

Pidgin made a very early appearance on the African poetic scene. As early as 1948, during the epoch of the pioneer poets, Gladys Casely-Hayford, a Ghanaian female poet published Take Um So. The volume is a small collection of three poems with moralistic message. The hallmark of the message of the collection is that people should accept whatever life offers them notwithstanding that there are people in better circumstances of life. Though Casely-Hayford collection like must poetry by the pioneer poets lacked serious literary ingredients, it may however be considered successful. This is because it is a major milestone being one of the foremost to experiment with Pidgin in the expression of poetic concerns.

Four years later, Dennis Osadebay, a Nigerian pioneer poet was to write another pidgin poem entitled "Black Man Trouble". His poem was published in the poetry collection, Africa Sings. As early as in 1952, Osadebay used this poem to establish that the Pidgin English is capable as serving as a 
medium through which weighty issues such as colonialism and its effect on the black man can be discussed on the poetic platform. Osadebay's effort was followed seven years later by Aig-Imoukhuede's “One Wife for One Man”. This poem was published in an anthology of poetry, Nigerian Student Verse, while Aig-Imoukhuede was still a student at University of Ibadan. In the poem, he decries the social issue of culture conflict

After the publication of "One Wife for One Man", Aig- Imoukhuede published a volume of poetry, Pidgin Stew and Sufferhead in 1982. Aig-Imoukhuede's Pidgin Stew and Sufferhead was followed by Mamman Vasta's Tori for Geti Bow Leg in 1985. This became the first collection of Nigerian poetry with all poems written in Pidgin. Vasta's poem further establishes the immense capability of Pidgin to serve as a vehicle of poetic communication of weighty issues. His poems are socially engaging. He condemns the prevalent social ethos in his society.

Tanure ojaide's experimentation with pidgin in one of his poems is also worth mentioning at this point. Ojaide's reputation as an established poet is not in doubt given his publication of over six volumes of poetry and the substantial criticism his work has attracted lately. Ojaide includes the pidgin poem entitled "I Be Somebody" in his collection, The Blood of Peace. Besides the pioneer poet, Dennis Osadebay, Aig-Imoukhuede, Mamman Vasta, Tanure Ojaide and Ezenwa Ohaeto, so may other poets have experimented with the Pidgin English as a medium of passing on their poetic messages. They include but are not limited to Tunde Fatunde, Pita Okute, A. Ajakaiye, Ogunlowo, Erapi, Udenwa, Ojeifo, Bello, Osita Ike, Obari Gomba, Promise okekwe, Tade Ipadeola and Humphrey Ogu.

Pidgin English and Its Ideological Implications in EzenwaOhaeto's Poetry Collections. 
In "Catch Naira For Me" the poet condemns materialism and the undue quest for luxury. It is this undue quest that turns a young girl sent to the university to study into a prostitute. It turns boys into armed robbers who do outrageous things. Even mothers and fathers who should be the custodians of moral value in the society are not spared as they do all sorts of abominable things just to conquer Naira and yet Naira keeps conquering them. Making the metonymic use of "Naira" to stand for money and all the beautiful things it can buy, the poet laments:

Naira you no dey strong pass dollar

Naira you no defeat pound sterling

Naira you never wrestle with Franc

But na him you dey beat us daily.

Of course the poet does not expect any actual war between the currencies. It is just his way of telling us that even the material things are in agreement with themselves while man is beaten into dropping his moral stand and succumbing the temptations that comes with extreme materialism. He concludes by saying; A beg catch naira for me/ I go show am how water pass garri. This is an obvious irony for there is nothing the poet will do to Naira. The fact that it is captured in Pidgin English also elicits humour so that through this subtle and humourous manipulation of the Pidgin English, the poet preaches the message that the value of a man does not consist in the abundance of things he has.

In "Typist 'im Question", the poet emphasizes that the service of everybody both typist and professor, carpenter and director are important for the smooth running of the society. Therefore equity, justice and fairness should guide the reward system that the society establishes. This he captures in the pidgin proverb: "na right hand dey washleft hand", implying that both high and the low need each other to function efficiently. In "Fingers no Equal", the poet concerns himself 
with the theme that inequality in the society is man-made and not just a product of destiny. He asks:

How fingers go dey equal

When waterdey drown person for desert

How fingers go dey equal

When human being don become god

How finger go dey equal

When one man go own all de land

How fingers go dey equal

When rat no gree him piken see road

$\mathrm{Na}$ bad belly make fingers no dey equal.

By juxtaposing the image of excess water and that the desert, the poet notes man has deified himself and has through "bad belly" caused inequality. In "Where God Dey", the poet calls on the people to fight their oppressor in that way, they are being God to themselves. According to Him: "Me I Know say God dey/ when person take him hand/ push him oppressor for ground.

In the collection, If To Say I Bi Soja, We read "Fire Game". Public officials who steal government funds need not be afraid; all that is needed is a little fire game. We read: If auditor dey come soon/and you don chop money/No fear/ $\mathrm{Na}$ one small match/ $\mathrm{Na}$ one cup petrol/ Dat one na essential commodity. The essential nuances of this poem as is captured in the pidgin English, will be totally lost if it is translated into English. "Politician $\mathrm{Na}$ Wind", we are presented with the unreliable nature of Nigerian politicians and their promises especially during electioneering. We see that "politician go promise everything/ E fit promise say e go bring God." The irony is succinctly captured by the pidgin used as we know that the politician can not bring God to his people. Abuse of power by the military is captured aptlyin "AS One General Pray". Hear the General's prayer:

God A beg you 
Give me big gun

Make I shoot enter office

Weder my people like me or not

Allah A beg you

Soja no bi suffer again

War don die finish

Make I take uniform get

De thing my brain no fit get

The message is clear, this block head "soja" will soon be lording it over university intellectuals just because he is wearing khaki uniform.

In "I Like My Kontri People", in one sweep the poet takes out on the society in which we see various institution of the state as completely failed. Starting from education symbolized by the village primary school with only one old table and chair for the school headmaster, to the hospitals where aspirin is administered for every sickness; we also see the judiciary with its unending adjournment "palava" which frustrates litigants' to point foregoing their rights. The irony in all these, is that as the state infrastructures are in a state of rot, the president and his officials are busy doing "owambe".

These pidgin poems are successful because of the poet s use of humour and extreme hyperboles that appear ridiculous while at the same time helping the reader realize the magnitude of the rot going on in the society, thereby leading to consciousness raising amongst the suppressed, who are expected to rise and question the status quo and work towards changing it.

\section{Pidgin English, Commitment and Relevance in Ezenwa- Ohaeto's Poetry.}

In the collection, If To Say I Bi Soja, the poem, "De Poem Go Talk" deals on commitment, relevance and functionality of poetry in changing the status quo in the society. In the first verse, the poet writes: "I wan poem wey go kill / you go take 
am shoot / E go travel hit target / I wan poem wey get fire/ you go talk am for mouth / na so e go bury bad thing." (13). Here, the poet compares the function of poetry to that of gun and fire. Poetry has the killing power of a gun. Just like a gun can be used to kill the perpetrators of evil in the society, so poetry serving as gun can be used to kill the evil they perpetrate. Poetry like fire has a purgative and purifying effect. It will purify the society of the anomalies in it. Further, in verse three, we read: "I wan poem wey go bite / no be poem like banana/ small thing e go spoil" (13). The poet does want poetry like banana because notwithstanding that banana is beautiful and sweet; it is very soft and therefore lacks the strength, resistance and resilience for the type of work which poetry is required to carry out in the society. One can therefore rightly deduce that for Ezenwa-Ohaeto, sweetness and beauty in poetry comes second to relevance, commitment and functionality. It is clear that a strong worded poetry or literary work is capable of such reformative work for history is full stories of societies that have been reformed or improved by the subtle influence of literature. The use of pidgin makes the reformative message of the poem direct and more immediate without the poem losing its beauty.

The themes of the poems "Messiah Don Come" and "I Like My Kontri People" are also relevant and committed to the political and social course of the poet's country, Nigeria. The former chronicles the political history of the country starting from the pre-independence era when the first generation Nigerian politicians struggled for the independence of the country to our recent past that is characterized by epileptic civilian government and incessant military interventions. The chronicling of these political and historical events does make the poem a mere political document. It rather shows the direction of the poet's commitment, this is because the poet in doing this is cautious to bring in relevant 
poetic elements and ingredients which ensure that the poetic quality of the work is not compromised. The later looks at the social anomalies in a country where both the leaders and the led put their selfish interest above the interest of the country to the detriment of the members of the public. This is exemplified by the fact that a doctor employed in the general hospital leaves the work he is supposed to do there. He would rather be in his private clinic pursuing his own personal enterprise. He is paid with the taxpayers' money for services he did not render and the society is worse for it. The issue of relevance, commitment and functionality is replete in all the poems in the two poetry collections that are the immediate focus of this study.

\section{Conclusion}

As has been illustrated, the use of the Pidgin English does not in any way reduce or diminish the relevance or commitment of the message in the entire collection. If anything, it brings the message to the fore and enhances its immediacy. The fact that pidgin induces humour ensures that the reader is not completely overwhelmed.

\section{Ogechi Blessing Ezeji}

Nnamdi Azikiwe University Awka, Nigeria

\section{Works Cited}

Achebe, Chinua. Morning Yet on Creation Day .Ibadan:

Heinemann Education Books, $1975 . \quad$ Print.

Eagleton, Terry. Marxism and Literary Criticism. London:

Routledge, 1976. Print.

Nnolim, Charles. Issues in African Literature. Yenegoa:

Treasure Books, 2009. Print. 
Ohaeto-Ezenwa. I Wan Bi President. Enugu: Delta Publications, 1988. Print.

_ _ _ $\quad$ If To Say I Bi Soja. Enugu: Delta Publications, 1998. Print.

- - - "Dimensions of Language in New Nigerian Poetry." Minstrels Never Die: Selected Writings of Ezenwa-Ohaeto. Ed. Ngozi Ezenwa-Ohaeto. Ibadan: Krafts Books Ltd, 2013. 283-294. Print. ..."Bridges of Orality: Nigerian Pidgin poetry." Minstrels Never Die: Selected Writings of Ezenwa-Ohaeto. Ed. Ngozi Ezenwa-Ohaeto. Ibadan: Krafts Books Ltd, 2013. 85-107. Print.

Soyinka, Wole. "Aesthetic Illusions." Third Press Review. 1 September/ October, 1975. 66. Print. 